staff. One aspect of this procedure is that only very rarely does the ombudsman bring face-to-face the complainant and those who are in the dock, so to speak. I should like to see this done more frequently as we know that some complainants are left with the feeling that points they have made have been side-stepped in the investigations and that they have not had the opportunity of refuting directly statements made by the people about whose actions or behaviour they are complaining.

The result of the painstaking investigations by the ombudsman of the grievances he deals with is more often than not to reject them. In 1982-3 he upheld 43 per cent of the cases he investigated. But on the evidence he can claim with justification that his recommendations are effective; in 1982-3 all were accepted by the health authorities concerned, and in quite a lot of cases this led to changes in procedures to the benefit of future patients.

The ombudsman recognises, in his Annual Report, paragraph 99, that the complainants whose grievances he does not uphold often remain 'anxious and unconvinced'. Perhaps a speedier and more direct procedure might mitigate this.

ELIZABETH ACKROYD Chairman of the Patients Association

\section{Medical Costs, Moral Choices, A Philosophy of Health Care Economics in America.}

Paul T Menzel. New Haven and London, Yale University Press, 1983, $\$ 22.50$

In his preface Menzel suggests that 'we have two very different reactions to contemporary health care'. He then contrasts the 'it is more important than anything else money can buy' reaction with the 'we are rankled by the incredible leverage over resources that the providers of medical care often appear to have' reaction. Who amongst us - apart possibly from some members of the medical profession - doesn't share this dual reaction?

I was intrigued by the task of reviewing this book: an economist invited by a medical doctor to review a book written by a philosopher. Despite the book's title, the objective of the author seems to be primarily to mount a defence of competitive forces as an efficient, equitable and moral mechanism for the supply of health care. Not that he advocates a wholly free market; but his sympathies clearly lie in that direction.

Menzel puts forward three 'fundamental and independent' principles in his ethical framework for health care: 'maximum human welfare, justice as distributional equality, and individual autonomy or consent'. On the first two Menzel writes that 'it is relatively easy to defend the independence of the equality principle from the principle of welfare'. This is doubtful at least in the eyes of this economist: if we provide open-heart surgery facilities for those living in remote areas to the extent that they then have as good access to such facilities as those living in large cities, is there no conflict with efficiency?

The discussion in chapters 2 and 3 on pricing life raises a number of important and interesting issues and it is here that the author's adherence to the virtue of individual autonomy is most apparent. As later emerges in the book, he is opposed to paternalism. Unfortunately he couches his discussion on this solely in terms of the poor. Two questions are avoided: if the poor choose paternalism, what then? and if everybody chooses paternalism, what then? The former, an issue of principle surely, is avoided by suggesting that there is no evidence in practice that the poor so choose. The second is not addressed - yet there is a sense in which one answer is 'the National Health Service'.

An NHS type of systęm has its dangers as Menzel points out. One such might be that there is 'no a priori reason physicians would not dominate an NHS'. In choosing how to deliver health care he poses the fundamental question: 'isn't the problem of justice for pluralistic competitive schemes less intractable than the moral problem of individual autonomy for an NHS? Maybe: but if in practice, in the face of his own very considerable ignorance and uncertainty about health and health care, the individual is prepared to forego his autonomy in the belief that the strength of the community interest may best serve his own welfare, then maybe not.

There is also a discussion of 'moral priorities' regarding the prevention versus treatment debate. Here however the moral issues seem to intrude unnecessarily. The same issue could be explained in a more matter of fact (but perhaps less stimulating) way by incorporating uncertainty and time preference through the economic technique of discounting the future.

The book raises many interesting issues. It steers a rather varied path, Sometimes it addresses the lofty concerns indicated at the beginning of this review. Sometimes it is more at the level of the inside of the jacket where we are told that one of the author's 'surprising conclusions' is that 'if individuals had to choose what to spend on their own health care . . . they would spend only a limited amount of the resources available to them'. But it's worth fighting through the latter type of point to follow Menzel on the former.

GAVIN MOONEY

Health Economics Research Unit Department of Community Medicine University of Aberdeen

\section{Social Work Values: an} Enquiry

Noel Timms. London, Routledge \&

Kegan Paul, 1983. £5.95

'This book is concerned with the current status of value-talk in social work, with delimiting some of the problems raised by such talk and with working towards some remedy for these.' This is the project Noel Timms sets himself in the opening chapter, though it should not lead the reader to assume that Timms is interested in discourse analysis, nor that he aims to produce a guidebook for social workers on the ethics of contemporary social work issues. The focus is softer, the treatment more discursive, the aim less applied: we are given a 'preliminary mapping of the terrain' rather than an architectural plan.

He has considerable fun in showing how social work theorists lay claim to a language of values in writing about their practice, while at the same time allowing an almost complete critical confusion over the content of some of the most central and cherished items, such as acceptance of the client, self-determination and respect for persons. Social work involves doing things to and for others (and indeed refusing to do things on occasion), and the morality of such actions can be, and has been, justified in various ways. Timms also argues that the problem cannot be narrowed to the individual casework relationship but must include wider 'social facts' of an economic, social or political nature.

After the demolition, the work of reconstruction is less assured. Instances of historical controversies in social work, or the contribution of economics and sociology to the question of values seem to give little hope of direction to the practitioner wanting an answer, as Timms himself recognises, to the question 'what ought I to do in my situa- 